\title{
Analysis of problem-solving skills: Impact of guided inquiry learning model based on Islamic values
}

\author{
Laila Puspita a,1,*, K. Komarudin b,2, Maya Astriani a,3 \\ a Biology Education Study Program, Faculty of Tarbiyah and Teacher Training, Universitas Islam Negeri Raden Intan Lampung, Jl. Letnan \\ Kolonel H Jl. Endro Suratmin Bandar Lampung, Lampung 35131, South Sumatra, Indonesia \\ ${ }^{b}$ Mathematic Education Study Program, Faculty of Tarbiyah and Teacher Training, Universitas Islam Negeri Raden Intan Lampung, \\ Jl. Letnan Kolonel H Jl. Endro Suratmin Bandar Lampung, Lampung 35131, South Sumatra, Indonesia \\ ${ }^{1}$ lailapuspita@radenintan.ac.id *; 2 komarudin@radenintan.ac.id; ${ }^{3}$ mayaastriani50@gmail.com \\ * corresponding author
}

\section{ARTICLE INFO ABSTRACT \\ Article history \\ Received February 09, 2020 \\ Revised June 06, 2020 \\ Accepted June 17, 2020 \\ Published July 21, 2020 \\ Keywords \\ Inquiry learning \\ Islamic values \\ Problem-solving skills \\ Islamic values have been recognized as the positive values need to be integrated in enhancing learning competencies including problem-solving skills. This study aimed to determine the influence of learning inquiry model based on Islamic values toward problem-solving skills of tenth-grade students in Bandar Lampung. This quasi- experimental research used posttest only control group design. The treatment for the experimental group used guided inquiry learning model based on Islamic values, whereas the direct instruction learning model was applied in control group. The students' problem-solving skills data were collected using a test. The data was analyzed using independent samples t-test. The results showed that there was a significant influence of guided inquiry learning model based on Islamic values toward students' problem-solving skills, $t(58)=2.807, p<.05$. The integration of Islamic values in the biology learning process can promote students' problem-solving skills. Therefore, guided inquiry learning model based on Islamic values can be an alternative model in empowering students' problem-solving skills.}

How to cite: Puspita, L., Komarudin, K., \& Astriani, M. (2020). Analysis of problem-solving skills: Impact of guided inquiry learning model based on Islamic values. JPBI (Jurnal Pendidikan Biologi Indonesia), 6(2), 347-354. doi: https://doi.org/10.22 219/jpbi.v6i2.11240

\section{INTRODUCTION}

Education has a role in human development . Education can bring change for a better life. Education, as a long-term investment, be a strategic value for life sustainability (Lento et al., 2014). Therefore, renewal in education should continue to improve the quality of education. It must be able to support the student to promote their problem-solving skill that is needed to cope with the everyday challenges (Binkley et al., 2014; Dunlosky, Rawson, Marsh, Nathan, \& Willingham, 2013; Glaze, 2018). Problem-solving skill is concerned with individual efforts to find combinations of various information that can be applied to deal with new situations (Binkley et al., 
2014). In other words, problem-solving is not just using data or abilities, but the process of acquiring a set of concepts at a higher level. Thus, problem-solving skills must be possessed by students. It is by getting students used to thinking in the process of determining the solution to a problem. According to Tornee, Bunterm, Lee, and Muchimapura (2019) the problem-solving process provides opportunities for students to take an active role in learning, searching for, and finding their information to be processed into concepts, principles, theories, and conclusions.

However, the facts of education in Indonesia currently show that students' problem-solving skills are still lacking (Septina, Farida, \& Komarudin, 2018). In fact, many researchers state that problem-solving skills are seen as a process to find combinations of a number of concepts that can be applied in an effort to solve problems (Bidokht \& Assareh, 2011; Kim \& Pegg, 2019; Ulger, 2018). Therefore, problem-solving skills must be promoting in the learning process. In the learning process, students can hone problem-solving skills by providing answers to several questions. These questions are in the form of problems that must be solved by students. Then, they will have opportunities to play an active role in studying, searching for, and finding their own information/data to be processed into concepts, principles, theories, and conclusions. This process can be carried out if the teacher chooses the right learning model. Thus, we need a learning model that encourages students to be able to hone problem-solving skills, one of which is by using a guided inquiry learning model.

The guided inquiry learning model is a learning activity that involves all the abilities of students to find and investigate something (object, person, or event) systematically, critically, logically, and analytically so that they can formulate their own findings confidently (Fang et al., 2016; Hyland, van Kampen, \& Nolan, 2019; Ratnaningrum, Chamisijatin, \& Widodo, 2016). The guided inquiry learning model can improve student learning outcomes by providing a long-term memory effect (Campbell, Zhang, \& Neilson, 2011; Fang et al., 2016). The knowledge that is built up by the mind itself based on facts and experiences obtained will be more easily accepted and relatively last longer in the mind. Students will learn best when faced with problems. On guided inquiry, students conduct investigations and find what they are looking for. In addition, in one group students help each other in solving problems so that students can learn better. Learning with the guided inquiry approach also provides stimulation to students' interest and desire to solve problems with their abilities because they are directly involved in the investigation (Şimşek \& Kabapinar, 2010; Spronken-Smith \& Walker, 2010; Veloo, Perumal, \& Vikneswary, 2013).

Several previous studies have examined inquiry learning models that have an impact on science process skills (Budiyono \& Hartini, 2016; Fitriyani, Haryani, \& Susatyo, 2017; Metaputri, Margunayasa, Garminah, \& Hum, 2016; Novitasari, Ilyas, \& Amanah, 2017; Susilawati \& Sridana, 2015; Suwandari, Taufik, \& Rahayu, 2018; Tornee et al., 2019), critical thinking skills (Amijaya, Ramdani, \& Merta, 2018; Nuriali, Busnawir, Samparadja, \& Ili, 2019; Nurmayani \& Doyan, 2018; Yeritia, Wahyudi, \& Rahayu, 2017), creative thinking skills (Aftriani, Muntari, Haris, \& Anwar, 2019; Ulandari, Putri, Ningsih, \& Putra, 2019), scientific attitude (Tornee et al., 2019; Widani, Sudana, \& Agustiana, 2019) and also problem-solving skills (Gillies, Nichols, \& Burgh, 2011; Ratnaningrum et al., 2016; Sayyadi, Hidayat, \& Muhardjito, 2016; Tornee et al., 2019). However, there are still few studies in Indonesia that examine the link between the guided inquiry learning model and problem-solving skills. In addition, there is still no integration of Islamic values in this learning model that intends to accommodate students' problem-solving skills.

The integration of Islamic values in learning is considered important, especially for Muslims. Moreover, science learning, because it directs students to be able to increase their sense of admiration and faith in the power of God Almighty (Elhoshi, Embong, Bioumy, Abdullah, \& Nawi, 2017; Piliang, Daulay, \& Siddik, 2017). Elhoshi et al. (2017) state that in the learning process it is also necessary to instill religious values in schools, by getting used to praying before starting learning and linking religious values with learning materials. The hope is that students will discover and realize Islamic values after students learn the concepts of science (including biology) and relate them to the greatness of God Almighty based on the Al-Quran and As-Sunnah.

For Muslims, studying and developing Islamic education to produce superior humans by sticking to the AlQuran and As-Sunnah is an absolute thing. The meaning of the Al-Quran and As-Sunnah are normative values that must be used like views, attitudes, and life goals (Elhoshi et al., 2017; Tan, 2014; Titrek, Yalçınkaya, \& Bayrakcl, 2014). In addition, these two sources are a guideline for human life as well as are believed to be ethical-normative values against all forms of injustice (Elhoshi et al., 2017), such as economic exploitation, political oppression, cultural domination, gender domination, and other practices. Therefore, it is imperative to integrate Islamic values in the learning process (Elhoshi et al., 2017; Nuriman \& Fauzan, 2017; Piliang et al., 2017; Tan, 2014; Titrek et al., 2014), so that students, who are Muslims, can determine their patterns of thought and behavior by referring to the Al-Quran and As-Sunnah. Thus, education becomes a place for students to change themselves and their way of thinking for the better. This study aims to see the impact of the integration of Islamic values in the guided inquiry learning model on the problem-solving skills of tenth graders in Bandar Lampung. 


\section{METHOD}

The research method used was a quasi-experimental research with a non-equivalent control group design. It involves an experimental group and a control group. Table 1 shows the research design used in this study. This study was conducted in the odd semester of the 2017/2018 academic year. The research population was tenth graders in Bandar Lampung, as many as 439 students. The sampling technique used was random cluster sampling. The samples used are consist of two groups, the experimental group (30 students) and the control group (30 students). The guided inquiry learning model based on Islamic values was implemented in the experimental group, while the control group was using direct instruction. The learning material used is related to the biodiversity topic.

Table 1. Research design

\begin{tabular}{ccc}
\hline dGroup & Treatment & Observation \\
\hline$E_{1}$ & $X_{1}$ & $Y$ \\
$E_{2}$ & $X_{2}$ & $Y$ \\
\hline
\end{tabular}

\begin{tabular}{ll}
\hline Description: \\
$\mathrm{E}_{1}$ & $:$ Experiment group \\
$\mathrm{E}_{2}$ & $:$ Control group \\
$\mathrm{X}_{1}$ & $:$ The guided inquiry learning model based on Islamic values \\
$\mathrm{X}_{2}$ & $:$ Direct instruction learning model \\
$\mathrm{Y}$ & $:$ Posttest
\end{tabular}

The students' problem-solving skill was measured using an essay test. The students' problem-solving skills indicators measured included: 1) understanding the problem; 2) creating a problem-solving plan, 3) implementing a problem-solving plan; and 4) making a conclusion. The learning process in both the control and the experimental group was carried out 3 times each. At the end of the meeting, students were given a posttest in the form of essay questions related to biodiversity to measure students' problem-solving skills. The essay questions were adjusted to the indicators of students' problem-solving skills. The instrument also has been tested for validity, reliability, difficulty level, and differentiation. The instruments used in this study had previously been validated by material experts. The data obtained was then classification according to the criteria of problem-solving skills (see Table 2). The data were analyzed using an independent samples t-test. Previously, some prerequisite tests, i.e. normality and homogeneity, were done.

Table 2. Qualification of students' problem-solving skill

\begin{tabular}{cc}
\hline Score $(\%)$ & Criteria \\
\hline $85,00-100$ & Excellent \\
$70,00-84,99$ & Good \\
$55,00-69,99$ & Enough \\
$40,00-54,99$ & Less \\
$0-39,99$ & Very less \\
\hline
\end{tabular}

\section{RESULTS AND DISCUSSION}

The results showed that students' problem-solving skills in the experimental and the control group were different (see Table 3). Table 3 explains that the mean score obtained from the experimental group was reach 78.53 , while the control class only 71.86 . Based on this average comparison, the experimental group was superior to the control one. Then, students' problem-solving skills in each indicator are presented in Table 4.

Table 3. Value problem-solving capabilities

\begin{tabular}{ccc}
\hline Score & Experiment group & Control group \\
\hline Highest & 98 & 90 \\
Lowest & 66 & 58 \\
Average & 78,53 & 71,86 \\
\hline
\end{tabular}

Table 4 explains that the experimental group was superior to the control group on all students' problemsolving skills indicators, except for the first one. For understanding the problem indicator, the two groups are stated at the same stage, namely excellent criteria, although the experimental group score is higher than the 
control. Furthermore, the normality test using the Liliefors test is displayed in Table 5. The test result showed that in both groups, experimental and control, have a value of $L$ count $\leq L$ table. It can be concluded that the data is normally distributed. The homogeneity test for the data using a two-variance or fisher homogeneity test showed that acquired $\mathrm{F}$ count $\leq \mathrm{F}$ table. So it can be said that the data is homogeneous (see Table 6).

Table 4. The students' problem solving skills in each indicator

\begin{tabular}{lcccc}
\hline \multirow{2}{*}{ Indicator } & \multicolumn{2}{c}{ Experiment group } & \multicolumn{2}{c}{ Control group } \\
\cline { 2 - 5 } & Percentage & Criteria & Percentage & Criteria \\
\hline Understanding the problem & $93,3 \%$ & Excellent & $88,2 \%$ & Excellent \\
Creating a problem-solving plan & $89,9 \%$ & Excellent & $83,2 \%$ & Good \\
Implementing a problem-solving plan & $88,8 \%$ & Excellent & $75,4 \%$ & Enough \\
Making a conclusion & $81,5 \%$ & Good & $73,2 \%$ & Enough \\
\hline
\end{tabular}

Table 5. The Liliefors test result of the data

\begin{tabular}{ccccc}
\hline Group & N & L count & L table $(\mathbf{0 . 0 5})$ & Conclusion \\
\hline Experimental & 30 & 0.14149 & 0.161 & Normal distribution \\
Control & 30 & 0.14110 & 0.161 & Normal distribution \\
\hline
\end{tabular}

Table 6. The homogenity test result of the data

\begin{tabular}{ccccc}
\hline Data & F count & F table (0.05) & Results & Conclusion \\
\hline Posttest & 1.24 & 1.85 & $F$ count $\leq F$ table & Homogen \\
\hline
\end{tabular}

Furthermore, data analysis was carried out using the independent samples t-test to observe whether there were significant differences in the experimental and control groups. The independent samples t-test results (see Table 7) show that the $t$ count is 2.887 greater than the $t$ table (2.00). It can be concluded that there is a significant difference between students' problem-solving skills in the experimental group and the control. As explained in Table 3, the mean in the experimental group was higher than the control group. In other words, there is an effect of using the guided inquiry learning model based on Islamic values on students' problemsolving skills in Bandar Lampung. The guided inquiry learning model that has been carried out causes students to give active responses during practicum, discussions, and presentations. The initial stage of this learning model begins by giving appreciation to students by asking some questions to explore the students' initial knowledge. In addition, the teacher provides motivation related to the Islamic values stated in the holy verses of the Al-Quran. This stage is carried out to attract student interest and motivation to participate in the learning process. According to Lin et al. (2020) this motivation is important and closely related to the students' problemsolving skills. That way students will be more enthusiastic and ready to solve the problems that will be presented in the learning process (Cain, 2019; Gillies et al., 2011).

Table 7. The independent samples t-test results of the data

\begin{tabular}{lcccc}
\hline & $t$ count & $t$ table & Results & Conclusion \\
\hline $\begin{array}{l}\text { The guided inquiry learning model based on Islamic } \\
\text { values }\end{array}$ & 2.887 & 2.00 & $t$ count $>\mathrm{t}$ table & Ho rejected \\
\hline
\end{tabular}

In the next stage, the teacher conveyed the learning objectives, namely students could mention the benefits of biodiversity, explain the level of biodiversity, and distinguish various levels of biodiversity (genes, types, and ecosystems). In this second stage, the teacher also divides students into heterogeneous groups. The formation of this group also has a role in the accommodation process of students' problem-solving skills. Students will respond to each other to find the right solution to the problem. Tornee et al. (2019) argue that the existence of this group provides a productive collaborative effect in problem-solving. One way to improve problem-solving skills is by utilizing collaboration among students (Elder, 2015; Karantzas et al., 2013; Kirschner, Paas, Kirschner, \& Janssen, 2011)

Then the teacher distributes student worksheets related to biodiversity in which there are recommendations that are in accordance with Islamic values, such as honest behavior, discipline, serious work to gain useful knowledge. The students' worksheet presented problems related to biodiversity. The teacher guides students in 
observing and identifying problems in students' worksheets. Students collaborate with friends in a group to understand problems. Koksal and Berberoglu (2014) state that this activity trains students to improve their ability to understand problems. Next, students in groups formulate hypotheses in accordance with the problems they already understand. To prove this hypothesis, students conducted small research. One of the topics is about the diversity level of genes. Students prepare tools and materials that will be used in an orderly and honest manner. In this activity, student can train their skill to create problem-solving plan. Students do careful planning to prove the hypothesis that has been formulated. Thus problem solving skills, especially in indicators of creating problem-solving plans can be maximally empowered. As some research results show that problemsolving skills can be accommodated when students make their own scientific inquiry (Karantzas et al., 2013; Piercey \& Cullen, 2017; Tornee et al., 2019; Yuliani, Adnan, Pierce Colfer, \& Indriatmoko, 2015)

Moreover, students observe and collect data regarding differences in skin color, height, blood type, hair shape, nose, dimples, eye color, and student weight in one class. At this stage, they implement their problemsolving plan. Students make direct observations according to the plan that has been set with the group. They analyze whether their problem-solving plan is correct or not. They make improvements if there are parts that are not suitable. According to Karantzas et al. (2013) this activity will train students to be critical and thorough in dealing with a problem. The results of the data obtained by the students were then reported by providing an integrated explanation of the holy verses of the Al-Quran that were in accordance with their findings.

Then the students presented the results of their small research by giving responses to other groups. At the end of learning, students and educators conclude learning activities and linking the existing biodiversity material with the holy verses of the Al-Quran, e.g. the surah Fatir verse 28. Students read Quranic verses related to the concept of biodiversity. Elhoshi et al. (2017) assert that this activity is worth to instill Islamic values in students and also strengthen their faith in God Almighty. Students' skills in concluding problem solving results are trained at this stage. The learning process in the experimental group showed that the students' responses, from the early stages to the end of learning, were more active, excited, and enthusiastic. Thus, the use of the guided inquiry learning model based on Islamic values can empower students' problem-solving skills, thereby encouraging the achievement of learning objectives. In addition, students can get a better understanding with this learning. It can be concluded that the integration of Islamic values in the biology learning process can promote students' problem-solving skills. Therefore, guided inquiry learning model based on Islamic values can be an alternative model in empowering students' problem-solving skills.

\section{CONCLUSION}

The implementation of the guided inquiry learning model based on Islamic values has a significant effect on students' problem-solving skills in Bandar Lampung. The integration of Islamic values in the biology learning process can promote students' problem-solving skills. Therefore, guided inquiry learning model based on Islamic values can be an alternative model in empowering students' problem-solving skills.

\section{REFERENCES}

Aftriani, D. N., Muntari, M., Haris, M., \& Anwar, Y. A. S. (2019). Pengaruh pembelajaran inkuiri terbimbing pada pelajaran kimia terhadap kemampuan berpikir kreatif siswa Kelas XI IPA SMAN 2 Mataram. Chemistry Education Practice, 1(2), 1-6. doi: https://doi.org/https://doi.org/10.29303/cep.v1i2.979

Amijaya, L. S., Ramdani, A., \& Merta, I. W. (2018). Pengaruh model pembelajaran inkuiri terbimbing terhadap hasil belajar dan kemampuan berpikir kritis peserta didik. Jurnal Pijar Mipa, 13(2), 94-99. doi: https:// doi.org/10.29303/jpm.v13i2.468

Bidokht, M. H., \& Assareh, A. (2011). Life-long learners through problem-based and self directed learning. Procedia Computer Science, 3, 1446-1453. doi: https://doi.org/10.1016/j.procs.2011.01.028

Binkley, M., Erstad, O., Herman, J., Raizen, S., Ripley, M., Miller-Ricci, M., \& Rumble, M. (2014). Defining twenty-first century skills. In Assessment and teaching of 21st century skills. doi: https://doi.org/10. 1007/978-94-007-2324-5_2

Budiyono, A., \& Hartini, H. (2016). Pengaruh model pembelajaran inkuiri terbimbing terhadap keterampilan proses sains siswa SMA. Wacana Didaktika, 4(2), 141-149. doi: https://doi.org/10.31102/wacanadidak tika.4.2.141-149 
Cain, J. (2019). We should pay more attention to student curiosity. Currents in Pharmacy Teaching and Learning, 11(7), 651-654. doi: https://doi.org/10.1016/j.cptl.2019.03.001

Campbell, T., Zhang, D., \& Neilson, D. (2011). Model based inquiry in the high school physics classroom: An exploratory study of implementation and outcomes. Journal of Science Education and Technology, 20(3), 258-269. doi: https://doi.org/10.1007/s10956-010-9251-6

Dunlosky, J., Rawson, K. A., Marsh, E. J., Nathan, M. J., \& Willingham, D. T. (2013). Improving students' learning with effective learning techniques: Promising directions from cognitive and educational psychology. Psychological Science in the Public Interest, 14(1), 4-58. doi: https://doi.org/10.1177/1529 100612453266

Elder, A. D. (2015). Using a brief form of Problem-Based Learning in a research methods class: Perspectives of instructor and students. Journal of University Teaching and Learning Practice, 12(1), 13. Retrieved from https://ro.uow.edu.au/jutlp/vol12/iss1/8/

Elhoshi, E. R. F., Embong, R., Bioumy, N., Abdullah, N. A., \& Nawi, M. A. A. (2017). The role of teachers in infusing Islamic values and ethics. International Journal of Academic Research in Business and Social Sciences, 7(5), 426-436. doi: https://doi.org/10.6007/IJARBSS/v7-i5/2980

Fang, S. C., Hsu, Y. S., Chang, H. Y., Chang, W. H., Wu, H. K., \& Chen, C. M. (2016). Investigating the effects of structured and guided inquiry on students' development of conceptual knowledge and inquiry abilities: a case study in Taiwan. International Journal of Science Education, 38(12), 1945-1971. doi: https://doi.org/10.1080/09500693.2016.1220688

Fitriyani, R., Haryani, S., \& Susatyo, E. B. (2017). Pengaruh model inkuiri terbimbing terhadap keterampilan proses sains pada materi kelarutan dan hasil kali kelarutan. Jurnal Inovasi Pendidikan Kimia, 11(2). doi: https://doi.org/https://doi.org/10.26740/jrpd.v2n1.p133-138

Gillies, R. M., Nichols, K., \& Burgh, G. (2011). Promoting problem-solving and reasoning during cooperative inquiry science. Teaching Education, 22(4), 427-443. doi: https://doi.org/10.1080/10476210.2011. 610448

Glaze, A. (2018). Teaching and learning science in the 21st century: Challenging critical assumptions in postsecondary science. Education Sciences, 8(1), 12. doi: https://doi.org/10.3390/educsci8010012

Hyland, D., van Kampen, P., \& Nolan, B. (2019). Introducing direction fields to students learning ordinary differential equations (ODEs) through guided inquiry. International Journal of Mathematical Education in Science and Technology. doi: https://doi.org/10.1080/0020739X.2019.1670367

Karantzas, G. C., Avery, M. R., MacFarlane, S., Mussap, A., Tooley, G., Hazelwood, Z., \& Fitness, J. (2013). Enhancing critical analysis and problem-solving skills in undergraduate psychology: An evaluation of a collaborative learning and problem-based learning approach. Australian Journal of Psychology, 65(1), 38-45. doi: https://doi.org/10.1111/ajpy.12009

Kim, M., \& Pegg, J. (2019). Case analysis of children's reasoning in problem-solving process. International Journal of Science Education, 41(6), 739-758. doi: https://doi.org/10.1080/09500693.2019.1579391

Kirschner, F., Paas, F., Kirschner, P. A., \& Janssen, J. (2011). Differential effects of problem-solving demands on individual and collaborative learning outcomes. Learning and Instruction, 21(4), 587-599. doi: https://doi.org/10.1016/j.learninstruc.2011.01.001

Koksal, E. A., \& Berberoglu, G. (2014). The effect of guided-inquiry instruction on 6th grade Turkish students' achievement, science process skills, and attitudes toward science. International Journal of Science Education, 36(1), 66-78. doi: https://doi.org/10.1080/09500693.2012.721942

Lento, E. M., Schleicher, A., Golden, M., Wilson, L., Koh, T. S., Prakash, A., ... Lewis, B. (2014). Transforming education for the next generation: A practical guide to learning and teaching with technology. (J. Rowell, Ed.). Intel@ Education. Retrieved from https://www.intel.com/content/dam/www/ public/us/en/documents/guides/transforming-education-next-generation-guide.pdf

Lin, X., Yang, W., Wu, L., Zhu, L., Wu, D., \& Li, H. (2020). Using an inquiry-based science and engineering program to promote science knowledge, problem-solving skills and approaches to learning in preschool children. Early Education and Development. doi: https://doi.org/10.1080/10409289.2020.1795333

Metaputri, N. K., Margunayasa, I. G., Garminah, N. N., \& Hum, M. (2016). Pengaruh model pembelajaran inkuiri terbimbing dan minat belajar terhadap keterampilan proses sains pada Siswa Kelas IV SD. MIMBAR PGSD Undiksha, 4(1). doi: https://doi.org/https://doi.org/10.23887/jppundiksha.v49i2.9013

Novitasari, A., llyas, A., \& Amanah, S. N. (2017). Pengaruh model pembelajaran inkuiri terbimbing terhadap keterampilan proses sains peserta didik pada materi fotosintesis Kelas XII IPA di SMA Yadika Bandar Lampung. Biosfer: Jurnal Tadris Biologi, 8(1), 91-104. doi: https://doi.org/10.24042/biosf.v8i1.1267 
Nuriali, W., Busnawir, B., Samparadja, H., \& Ili, L. (2019). Pengaruh model pembelajaran inkuiri terbimbing terhadap kemampuan berpikir kritis matematika ditinjau dari kemandirian belajar Siswa SMK. Jurnal Pembelajaran Berpikir Matematika (Journal of Mathematics Thinking Learning), 3(2). doi: https://doi.org/ 10.24853/fbc.4.2.145-154

Nuriman, \& Fauzan. (2017). The influence of Islamic moral values on the students' behavior in Aceh. Dinamika IImu, 17(2), 275-290. doi: https://doi.org/10.21093/di.v17i2.835

Nurmayani, L., \& Doyan, A. (2018). Pengaruh model pembelajaran inkuiri terbimbing terhadap hasil belajar fisika peserta didik. Jurnal Penelitian Pendidikan IPA, 4(2). doi: https://doi.org/10.29303/jpft.v4i1.548

Piercey, V., \& Cullen, R. (2017). Teaching inquiry with linked classes and learning communities. PRIMUS, 27(1), 20-32. doi: https://doi.org/10.1080/10511970.2016.1184727

Piliang, M. Z., Daulay, H. P., \& Siddik, D. (2017). An analysis of integrated Islamic school Al Ulum in Medan, Indonesia. IOSR Journal Of Humanities And Social Science (IOSR-JHSS), 22(4), 100-107. doi: https://doi.org/10.9790/0837-220406100107

Ratnaningrum, D. A., Chamisijatin, L., \& Widodo, N. (2016). Penerapan pembelajaran guided inquiry untuk meningkatkan motivasi dan hasil belajar IPA pada siswa Kelas VIII-A SMP Muhammadiyah 2 Batu. Jurnal Pendidikan Biologi Indonesia, 1(2). doi: https://doi.org/10.22219/JPBI.V1|2.3334

Sayyadi, M., Hidayat, A., \& Muhardjito, M. (2016). Pengaruh strategi pembelajaran inkuiri terbimbing dan terhadap kemampuan pemecahan masalah fisika pada materi suhu dan kalor dilihat dari kemampuan awal siswa. Jurnal Inspirasi Pendidikan, 6(2), 866-875. doi: https://doi.org/10.21067/jip.v6i2.1325

Septina, N., Farida, F., \& Komarudin, K. (2018). Pengembangan lembar kerja siswa dengan pendekatan saintifik berbasis kemampuan pemecahan masalah. Jurnal Tatsqif, 16(2), 160-171. doi: https://doi.org/ 10.20414/jtq.v16i2.200

Şimşek, P., \& Kabapinar, F. (2010). The effects of inquiry-based learning on elementary students' conceptual understanding of matter, scientific process skills and science attitudes. In Procedia - Social and Behavioral Sciences (Vol. 2, pp. 1190-1194). doi: https://doi.org/10.1016/j.sbspro.2010.03.170

Spronken-Smith, R., \& Walker, R. (2010). Can inquiry-based learning strengthen the links between teaching and disciplinary research? Studies in Higher Education, 35(6), 723-740. doi: https://doi.org/10. 1080/03075070903315502

Susilawati, S., \& Sridana, N. (2015). Pengaruh model pembelajaran inkuiri terbimbing terhadap keterampilan proses sains siswa. Biota, 8(1), 27-36. doi: https://doi.org/10.20414/jb.v8i1.56

Suwandari, P. K., Taufik, M., \& Rahayu, S. (2018). Pengaruh model pembelajaran inkuiri terbimbing terhadap penguasaan konsep dan keterampilan proses sains fisika peserta didik kelas XI MAN 2 Mataram tahun pelajaran 2017/2018. Jurnal Pendidikan Fisika dan Teknologi, 4(1), 82-89. doi: https://doi.org/10. 29303/jptt.v4i1.541

Tan, C. (2014). Educative tradition and Islamic schools in Indonesia. Journal of Arabic and Islamic Studies, 14, 47-62. doi: https://doi.org/10.5617/jais.4638

Titrek, O., Yalçınkaya, M., \& Bayrakcı, M. (2014). Islamic moral values of pre-service teachers for secondary schools. International Journal of Human Sciences, 11(1), 469-480. doi: https://doi.org/10.14687/ijhs.v1 $1 \mathrm{i} 1.2831$

Tornee, N., Bunterm, T., Lee, K., \& Muchimapura, S. (2019). Examining the effectiveness of guided inquiry with problem-solving process and cognitive function training in a high school chemistry course. Pedagogies, 14(2), 126-149. doi: https://doi.org/10.1080/1554480X.2019.1597722

Ulandari, N., Putri, R., Ningsih, F., \& Putra, A. (2019). Efektivitas model pembelajaran inquiry terhadap kemampuan berpikir kreatif siswa pada materi teorema pythagoras. Jurnal Cendekia: Jurnal Pendidikan Matematika, 3(2), 227-237. doi: https://doi.org/https://doi.org/10.31004/cendekia.v3i2.99

Ulger, K. (2018). The effect of problem-based learning on the creative thinking and critical thinking disposition of students in visual arts education. Interdisciplinary Journal of Problem-Based Learning, 12(1). doi: https://doi.org/10.7771/1541-5015.1649

Veloo, A., Perumal, S., \& Vikneswary, R. (2013). Inquiry-based instruction, students' attitudes and teachers' support towards science achievement in rural primary schools. Procedia - Social and Behavioral Sciences, 93, 65-69. doi: https://doi.org/10.1016/j.sbspro.2013.09.153

Widani, N. K. T., Sudana, D. N., \& Agustiana, I. G. A. T. (2019). Pengaruh model pembelajaran inkuiri terbimbing terhadap hasil belajar IPA dan sikap ilmiah pada siswa Kelas V SD Gugus I Kecamatan Nusa Penida. Journal of Education Technology, 3(1), 15-21. doi: https://doi.org/10.23887/jet.v3i1.17959 
Yeritia, S., Wahyudi, W., \& Rahayu, S. (2017). Pengaruh model pembelajaran inkuiri terbimbing terhadap penguasaan konsep dan kemampuan berpikir kritis fisika peserta didik kelas X SMAN 1 Kuripan Tahun Ajaran 2017/2018. Jurnal Pendidikan Fisika dan Teknologi, 3(2), 181-187. doi: https://doi.org/10.29303/ jpft.v3i2.398

Yuliani, E. L., Adnan, H., Pierce Colfer, C. J., \& Indriatmoko, Y. (2015). Problem-solving versus appreciative inquiry approaches in community-based conservation. Forests Trees and Livelihoods, 24(2), 97-111. doi: https://doi.org/10.1080/14728028.2014.954638 